\title{
The Institutionalization of the Congregational Singing of Metrical Psalms in the Elizabethan Reformation
}

\author{
Andrew Poxon* \\ Durham University
}

\begin{abstract}
Previous scholarship has often employed the categories of 'voluntary' and 'established' religion when studying lay involvement in parish religion; yet these categories do not provide adequate space for the vitality of lay religious initiatives during the English Reformation. Through a study of the singing of metrical psalms, this article argues that the categories of 'inspiration' and 'institution' provide a more nuanced understanding of lay religious initiatives during the English Reformation. It outlines the ways in which the singing of metrical psalms, taken from the Sternhold and Hopkins Whole Booke of Psalmes, moved from its origins in domestic devotions, through inspirational initiative, to become an institutionalized part of the worship of English congregations. This process developed over many years, coming to the fore during the reign of Elizabeth I, yet even once institutionalization had occurred, inspiration could still arise, providing fresh direction and development.
\end{abstract}

In October 1559, the clergy of Exeter Cathedral complained to the royal visitors that a group from London who had travelled to attend a fair, along with some local sympathizers, had marched into the cathedral daily to sing psalms. The clergy protested about two things: their own worship was being disrupted, and (worse still) men and women were singing alongside one another, even sitting in the seats of the

* Department of Theology and Religion, Durham University, Abbey House, Palace Green, Durham, DH1 3RS. E-mail: andrew.r.poxon@durham.ac.uk. I would like to thank all those who asked questions or offered comments when the paper was first delivered. I also wish to thank the two anonymous reviewers and the editors, who offered criticisms and comments which have, I hope, made the article much stronger. I would like to thank in particular Christopher Marsh and Andrew Spicer for valuable comments and advice, and Alec Ryrie for reading through numerous drafts and offering sage guidance. I also wish to thank AHRC Northern Bridge for the funding which allowed the research in this article to take place. creativecommons.org/licenses/by/4.0/), which permits unrestricted re-use, distribution, and reproduction in any medium, provided the original work is properly cited. 
vicars choral. They did not, however, secure their desired outcome, since the lead visitor was none other than bishop-elect, John Jewel, who, rather than condemn the visitors, praised the laity for their desire 'to sing a Psalm for their greater comfort and better stirring up of their hearts to devotion ... according to the use and manner of the Primitive Church'. In turn, Jewel secured a letter from Archbishop Parker giving the psalm-singers his blessing. ${ }^{1}$

To the clergy of Exeter Cathedral, and no doubt many locals too, the singing of metrical psalms was a significant disruption to their normal order; an example of inspirational practices in conflict with the institutional worship to which the cathedral had become accustomed. Their complaints demonstrate that they viewed the singing as unacceptable and impulsive and assumed that the royal visitors would agree. Unfortunately for them, the singing of metrical psalms by men and women, in both congregational and domestic settings, had developed as a significant element in the worship of English exiles on the Continent during the reign of Mary I, and would increase in popularity and prominence throughout the reign of Elizabeth I. ${ }^{2}$

Previous scholarship has often employed the categories of 'voluntary' and 'official' religion when discussing such conflicts or lay religious initiatives more generally. Yet it is the argument of this article that the categories of 'institution' and 'inspiration' provide a more nuanced framework for understanding the English Reformation. Throughout this article 'inspirational' will be applied to practices, rituals or outworkings of faith which took place both in church and outside it, which may be performed or participated in by individuals or

${ }^{1}$ Herbert Reynolds, ed., The Use of Exeter Cathedral (London, 1891), 54, cited in Alec Ryrie, 'The Psalms and Confrontation in English and Scottish Protestantism', ARG 101 (2010), 114-37, at 125 .

2 Ian Green, Print and Protestantism in Early Modern England (Oxford, 2000), 503-52; idem, "All people that on earth do dwell, Sing to the Lord with cheerful voice": Protestantism and Music in Early Modern England', in Simon Ditchfield, ed., Christianity and Community in the West (Aldershot, 2001), 148-64; Christopher Marsh, Music and Society in Early Modern England (Cambridge, 2010), 405-53; Jonathan Willis, Church Music and Protestantism in Post-Reformation England: Discourses, Sites and Identities (Farnham, 2010), 121-8; Beth Quitslund and Nicholas Temperley, The Whole Book of Psalms, Collected into English Metre by Thomas Sternhold, John Hopkins, and Others: A Critical Edition of the Texts and Tunes, 2 vols (Tempe, AZ, 2018), especially 2: 505-621. While her concern is principally with Scotland, see also Jane Dawson, "The Word did everything": Readers, Singers and the Protestant Reformation in Scotland c.1560-c.1638', Scottish Church History 46 (2017), 1-37, especially 31-5. 
groups, and which are not dependent on the leadership or approval of church authorities. 'Institution(al)' will be taken to refer to practices which were a regular, assumed part of the worship or religious experience of early modern people. The absence of such an institutionalized practice may disturb those who think this practice to be a normal part of their involvement and interaction with their religion and its outworking, whether individual or collective, parish-focused or not. Such practices may not have been officially mandated by the relevant authorities, yet nevertheless assumed a role in worship or religious experience which was akin to those practices which did receive this mandate. In this sense, an 'inspirational' practice could arise and over time become institutionalized, a process which is distinct from when, and whether, the practice was ever officially permitted or mandated.

Christopher Haigh's categories of Reformation from above and from below provide a helpful lens through which we can begin to understand the categories of 'inspiration' and 'institution'. In Haigh's account, the 'Reformation from above' model argued that the English Reformation was 'enforced from the centre by deliberate governmental action'. ${ }^{3}$ While local government and authorities could provide the impetus for the imposition of these policies, or a block on them, and while 'Reformation from below' may subsequently have taken over, the Reformation was first and foremost directly mandated by those at the centre who held political power. This argument is regularly implied through the use of the term 'official' (as opposed to 'voluntary'), referring to those religious activities which received a mandate and were thus implemented in the localities, in theory if not necessarily in practice. Meanwhile the alternative perspective, namely 'Reformation from below', 'means that the new religion soon seized the imaginations of artisans and peasants'. ${ }^{4}$ Haigh's terminology opens up the categories of inspiration and institution helpfully, and particularly the congruence between 'inspiration' and 'Reformation from below', in which the key impetus for reform comes from the common people, rather than through politically mandated changes.

3 Christopher Haigh, 'The Recent Historiography of the English Reformation', in idem, ed., The English Reformation Revised (Cambridge, 1987), 19-33, at 20.

${ }^{4}$ Ibid. 24. 
In the Exeter example above, we see inspiration operating for the clergy, since their view is that there is no official mandate for the practice of psalm singing, but also for the group from London since they nevertheless choose to sing psalms, in spite of the lack of official direction. We see the category of institution in the approach of the clergy who feel that the singing of metrical psalms does not fit with the form of worship to which they are accustomed, and yet for the group from London the singing of psalms has become institutionalized so that they now see it as an essential expression of worship. Haigh's categories are helpful here because we see the interaction of 'Reformation from above' in the cathedral's disrupted worship and 'Reformation from below' in the singing of psalms by the group from London. The latter category here reflects an inspirational practice - which is to say, not officially mandated - which had become institutionalized in the group's understanding of worship.

This article will use the singing of metrical psalms as a means of critiquing older categories of 'voluntary and 'established' and demonstrating that a framework based on 'inspiration' and 'institution' allows us to see that lay religious initiatives could develop and flourish, even in a period of religious uncertainty and strict control, eventually becoming institutionalized as practices which later came to be considered central parts of the worship of English congregations.

\section{The Historiography of 'Voluntary' Religion}

A full account of voluntary religion is offered in volume 23 of Studies in Church History. The editors, Bill Sheils and Diana Wood, define 'voluntary religion' as referring to those 'societies and associations which brought together groups of like-minded individuals for a religious purpose either within or without the life of the broader church', yet which, as Patrick Collinson noted in the introduction, 'at no time claimed to be churches, but professed to perform a role which their leaders and adherents understood to be complementary to that of the Church or churches, providing additional emotional satisfaction, social support and fellowship'. ${ }^{5}$ Indeed, much of Collinson's work could be seen as an attempt to define and document the differences and similarities, as well as the relationship between voluntary and

5 W. J. Sheils and Diana Wood, 'Preface', to eidem, eds, Voluntary Religion, SCH 23 (Oxford, 1986), viii; Patrick Collinson, 'Introduction', ibid. xii. 
involuntary or compulsory religion during the English Reformation. ${ }^{6}$ In particular, we may note his work on the differences between those 'groups' or 'communities' with separatist potential, whom historians loosely think of as 'puritans'.$^{7}$ It is, however, in the context of his work on the English conventicle that Collinson's assertions regarding voluntary religion are articulated most clearly. ${ }^{8}$ Conventicles, he observes, were a form of voluntary religion in that members would meet together and learn, repeat, discuss, sing or hear what they wanted, or travel to other communities or parishes, enjoying fellowship alongside their attendance at the parish church. ${ }^{9}$

For all the power of Collinson's framework, it leaves open a number of questions which are important when we consider metrical psalmody. In particular, it does not allow us to address the kind of process by which the singing of metrical psalms moved from inspiration to become an institutionalized part of the worship of English congregations. Nor does it allow for the fluidity that characterized the singing of metrical psalms, as the practice moved from domestic, private devotions into parish worship - and back again - in the way that most other beliefs and practices of conventicles and puritans did not. And while voluntary religion for Shiels, Wood and Collinson is focused on 'groups' and 'communities' who met alongside their attendance at church, the singing of metrical psalms was equally a part of individual, private devotion, which then also attained a collective role in the worship of English congregations after the accession of Elizabeth I and the return of the Marian exiles.

6 For the use of the term 'involuntary', see Collinson, 'Introduction', xii; Beat Kümin, 'Voluntary Religion and Reformation Change in Eight Urban Parishes', in Patrick Collinson and John Craig, eds, The Reformation in English Towns, 1500-1640 (Basingstoke, 1998), 175-89, at 176. Kümin also uses the term 'compulsory': ibid.

7 See Patrick Collinson, The Religion of Protestants: The Church in English Society 15591625 (Oxford, 1982), 268 (on 'community'); idem, The Elizabethan Puritan Movement (Oxford, 1990), 27 (on 'the hotter sort of Protestants'); idem, 'Night Schools, Conventicles and Churches: Continuities and Discontinuities in Early Protestant Ecclesiology', in Peter Marshall and Alec Ryrie, eds, The Beginnings of English Protestantism (Cambridge, 2002), 209-35, at 215 (on 'semi-separatist'); idem, Religion of Protestants, 274-83 (on 'separatist', 'semi-separatist' and 'quasi-separatist').

${ }^{8}$ For definitions of conventicle, see Collinson, 'Night Schools', 214; compare Patrick Collinson, 'The English Conventicle', in Sheils and Wood, eds, Voluntary Religion, 223-59, at 230.

9 Collinson argues that they are thus 'better termed semi-separatist' or 'quasi-separatist': 'Night Schools', 215; idem, Religion of Protestants, 274; see also idem, 'English Conventicle'. 
Beat Kümin has offered the clearest statement of the 'voluntary religion' hypothesis as applied to practice rather than to mere association, looking at both the pre- and post-Reformation periods. Kümin charts the high levels of lay involvement in the medieval period, demonstrating that the religious transformations of the mid-Tudor period ushered in a dramatic stripping of many of the opportunities for lay expressions of 'voluntary religion'. He defines 'voluntary religion' as 'collective spiritual activities pursued in addition to or instead of those prescribed by the Church'. ${ }^{10}$ Through rigorous analysis of the financial transactions found in the churchwardens' accounts of eight urban parishes, Kümin suggests that the Tudor Reformation removed the majority of the medieval parish's opportunities for 'voluntary religion', as certain forms of lay devotion were stripped away, or their role dramatically altered with a 'general trend towards a more restrictive religious atmosphere'. ${ }^{11} \mathrm{He}$ concludes that these religious changes of the mid-Tudor decades 'were enforced too quickly, too uniformly, too comprehensively, and also reversed too frequently to reflect genuine grass-roots developments. In fact, any divergent parochial initiative would have been stifled by the flood of meticulous guidelines and the intensive supervision. ${ }^{12}$

Eamon Duffy has also made a significant contribution regarding the impact of the English Reformation on voluntary religious activities. In The Stripping of the Altars, Duffy argues that the high level of lay commitment and investment in traditional religion was largely destroyed by the Reformation. ${ }^{13}$ However, the framework offered by Duffy does not allow for the sort of inspirational lay initiative we see during the English Reformation, such as the singing of metrical psalms; moreover he does not fully address the means through which inspirational practices become institutionalized.

Instead, examination of the singing of metrical psalms demonstrates that what Kümin calls 'genuine grass-roots developments' did take place during the English Reformation, ${ }^{14}$ and that, over time, the practice flourished and became institutionalized in public worship. The singing of metrical psalms in England originated during

${ }^{10}$ Kümin, 'Voluntary Religion', 176.

11 Ibid. 185.

12 Ibid. 186.

13 Eamon Duffy, The Stripping of the Altars: Traditional Religion in England, c. 1400 c. 1580 (New Haven, CT, 2005; first publ. 1992).

${ }^{14}$ Kümin, 'Voluntary Religion', 186. 
the reign of Edward VI and at the initiative was originally directed towards the young king and his entourage. ${ }^{15}$ Indeed, Thomas Sternhold's first edition of metrical psalms, published around 1549 under the title Certayne Psalmes chose[n] out of the Psalter of Dauid, and drawe [n] into Englishe Metre by Thomas Sternhold, contained a dedicatory preface addressed to the boy king. ${ }^{16}$ In it, Sternhold praised Edward for the fact that his 'tender and Godly zeale doethe more delyghte in the holye songes of veritie than in anye fayned rimes of vanitie'. ${ }^{17}$ Sternhold urged Edward 'to se[e] \& read them your selfe, but also to $\operatorname{com}[\mathrm{m}]$ and them to be song to you of others' ${ }^{18}$ Yet while its origins lay in the Tudor court, the singing of metrical psalms soon spread into domestic devotions. By the death of Edward VI, it seems likely that some ten thousand copies of English translations of metrical psalms by Sternhold and Hopkins had been printed, and those that survive reveal that the singing of metrical psalms developed alongside other devotional practices facilitated through primers and catechisms (which are often bound with copies of metrical psalms), all of which were viewed as fully in keeping with the Edwardian Reformation. ${ }^{19}$ The significance of metrical psalmody in the Edwardian period may have been significantly underestimated.

Yet while the practice of singing psalms seems to have been relatively common in private devotions during the reign of Edward VI, its migration into public worship was by no means an obvious transition. Crucial to this process was the time spent by English exiles on the Continent, where congregational singing of metrical psalms was relatively well established. It was only following the return of English exiles that the congregational singing of metrical psalms became established in English parishes, and I would argue that this was a result of the inspirational initiative of ordinary parishioners. Central to this practice was the publication in 1562 of The Whole Booke of Psalmes, which contained at least one metrical version of each of

\footnotetext{
15 Marsh, Music and Society, 406-7; Beth Quitslund, The Reformation in Rhyme: Sternhold, Hopkins and the English Metrical Psalter, 1547-1603 (Aldershot, 2008), especially $19-20$.

16 On the dating of this first edition see Quitslund, Reformation in Rhyme, 27-8.

17 Thomas Sternhold, Certayne Psalmes chose[n] out of the Psalter of Dauid, RSTC 2419 (London, c.1549), preface, fol. Aiiir.

18 Sternhold, Certayne Psalmes, sig. Aiiir.

19 My doctoral research, due for completion in September 2021, will investigate this further.
} 
the hundred and fifty Psalms, along with sixty-five tunes to which they could be sung. Evidence for the quick uptake and use of the Whole Booke of Psalmes is found in the purchasing of metrical psalms as recorded in churchwardens' accounts. ${ }^{20}$ As will be discussed below, the purchasing of these books for use in congregational worship was not mandated by the Elizabethan regime, and thus relied on the initiative of ordinary members of the congregation. Further, the process of purchasing for inclusion in congregational worship would have been doomed to failure had the whole congregation not approved, and so establishing the practice must also have involved more than a few individuals. This inclusion of metrical psalmody into worship, and the support necessary for it, counter Kümin's conclusion that the religious changes of the mid-Tudor decades suppressed 'genuine grass-roots developments'.

Further, by claiming that the religious changes of the mid-Tudor period 'were enforced too quickly, too uniformly, too comprehensively, and also reversed too frequently to reflect genuine grass-roots developments', Kümin assumes that genuine grass-roots movements can only develop slowly. ${ }^{21}$ Yet we can see that the singing of metrical psalms spread rapidly from its inspirational origins to occupy a more institutionalized place in the worship of English congregations and in private devotions, particularly following the accession of Elizabeth I and the return of the Marian exiles. While in exile, English Protestants were influenced by congregational psalm singing, particularly in Wesel, Strasbourg and (most importantly) Geneva, developing further the corpus of texts and tunes which had been produced by Sternhold and Hopkins. ${ }^{22}$ In England during Mary I's reign, John Foxe records Protestant martyrs singing psalms. For example, on 8 August 1555, John Denley of Maidstone sang a psalm while being burnt for heresy, stopping only when a burning log was thrown at his head, and then finally to '[yield] his spirit into the hands of God'. ${ }^{23}$

\footnotetext{
20 On purchasing of metrical psalms as recorded in churchwardens' accounts, see the discussion and n. 26 below.

21 Kümin, 'Voluntary Religion', 186.

22 Marsh, Music and Society, 407; Robin A. Leaver, 'Goostly psalms and spirituall songes': English and Dutch metrical psalms from Coverdale to Utenhove (Oxford, 1991), 175-237; Timothy Duguid, Metrical Psalmody in Print and Practice: English 'Singing Psalms' and Scottish 'Psalm Buiks', c. 1547-1640 (Aldershot, 2014), especially 14-48.

23 John Foxe, The Unabridged Acts and Monuments Online (1570) or TAMO (Digital Humanities Institute, Sheffield, 2011), 1906, online at: <https://www.dhi.ac.uk/foxe/>. Other examples can be found in the online edition: ibid. 2162, 2303, 2253, 2004, 2142. These will be considered in my forthcoming thesis.
} 
Following the accession of Elizabeth I, exiles returned to England with editions of metrical psalms they had compiled, singing from which had become an institutionalized part of their church services, complementing the domestic, devotional role psalm-singing had played before Mary's accession. These versions provided the basis for the Whole Booke of Psalmes (1562), the edition from which all other collections of metrical psalms would develop over the following century-and-a-half. With the publication of this collection and the growing number of parishes incorporating the singing of psalms into their worship, the practice moved from the domestic to the congregational sphere for the first time in England. In so doing, it shifted from an 'inspirational' movement towards institutionalization. Initially, its inclusion was initiated by individuals as well as groups such as congregations, and while the singing of metrical psalms did not receive an official mandate - in contrast to, for example, the requirement that parishes purchase and use the Book of Common Prayer - the practice established itself as a central element of congregational worship. In this early phase, to use Haigh's terminology, the process of institutionalization occurred 'from below' in that individual parishes decided to adopt it, as opposed to 'from above' as a requirement for all parishes. ${ }^{24}$ Indeed, as early as April 1559, the London chronicler Henry Machyn recorded how 'boyth prychers and odur [others], and [women,] [sang] of a nuw fassyon'. ${ }^{25}$ He followed this up that September, recording that at 'mornyng prayer at sant Antholyns in Boge-row, after Geneve fassyon ... men and women all do syng, and boys', and 1561 he recorded the singing of a psalm in church during a funeral. ${ }^{26} \mathrm{We}$ can see, therefore, that, even from the beginning of Elizabeth's reign, the singing of metrical psalms was ceasing to be a purely inspirational practice and was beginning to find institutional expression in the public worship of certain parishes.

This parish initiative can be seen in a brief survey of churchwardens' accounts from the early decades of Elizabeth's reign. ${ }^{27}$ In

\footnotetext{
${ }^{24}$ Haigh, 'Historiography', 19-21.

25 J. G. Nichols, ed., The Diary of Henry Machyn, Citizen and Merchant-Taylor of London, 1550-1563 (London, 1848), 193.

${ }^{26}$ Ibid. 212, 247.

27 This is only a preliminary survey and much more work needs to be done, but the accounts outlined here provide a sample of a larger trend. For a more comprehensive account of churchwardens' accounts in Elizabethan parishes, see Willis, Church Music, 121-8, for metrical psalmody; see also Quitslund and Temperley, Whole Book of
} 
1560, the parish of St Stephen Walbrook purchased 'a service bok with the psalter and the homilies', and two psalm books, while the parish of St Mary Woolnoth purchased 'ii psalme books in myter for the churche' for the price of 16 pence. ${ }^{28}$ In 1559, the parish of St Margaret Pattens bought 'iiii salme books of Awstyne' and 'v Jenova bokes', and an inventory of 1567 reveals that the church also owned 'a psalter bocke in prose and also in myter with homilies'. ${ }^{29}$ Finally, in 1570 the parish of St Ethelburga the Virgin, Bishopsgate, bought 'two psalters and twoo bookes of Jeneva psalmes' ${ }^{30}$ The evidence from churchwardens' accounts (covered broadly here, but more thoroughly by Jonathan Willis) suggests that throughout the reign of Elizabeth I the singing of metrical psalms as a congregational as well as a domestic practice moved from inspirational origins at the beginning towards a more institutionalized place in the worship of English congregations. ${ }^{31}$ As will be explored further below, the Elizabethan regime eventually recognized this development by prescribing metrical psalms for the annual service to celebrate the queen's accession.

Finally, the singing of metrical psalms demonstrates that not all lay religious initiatives were suppressed by the various guidelines, visitations and court proceedings. This particular practice developed in part due to the ambiguity of the Elizabethan Injunctions with relation to music or singing in worship. The injunctions of 1559 provided that:

... for the comforting of such as delight in music, it may be permitted that in the beginning or in the end of common prayers, either at

Psalms, 2: 1023-7. When reviewing churchwardens' accounts, it is important to note that metrical psalms are described variously as 'Psalms books', 'in metre', 'Jeneva psalms' and 'singing psalms', while the prose versions are typically referred to as 'psalters': Jonathan Willis, 'Ecclesiastical Sources', in Laura Sangha and Jonathan Willis, eds, Understanding Early Modern Primary Sources (Abingdon, 2016), 58-77; John Craig, 'Psalms, Groans and Dogwhippers: The Soundscape of Worship in the English Parish Church, 1547-1642', in Will Coster and Andrew Spicer, eds, Sacred Space in Early Modern Europe (Cambridge, 2005), 104-23, at 106.

28 London, LMA, St Stephen Walbrook, 1551-1738, P69/STE2/B/008/MS00593/002, fol. 44r; St Mary Woolnoth, 1539-1641, P69/MRY17/B/006/MS01002/001A, fol. 96r. 29 LMA, St Margaret Pattens, 1555-1760, P69/MGT4/B/004/MS04570/002, pp. 3-4, 12; St Mary Woolnoth, P69/MRY17/B/006/MS01002/001A, fol. 96r.

${ }^{30}$ LMA, St Ethelburga the Virgin, Bishopsgate, 1569-1681, P69/ETH/B/006/ MS04241/001, fol. 69.

31 Willis, Church Music, 121-8. 
morning or evening, there may be sung an hymn or suchlike song, to the praise of Almighty God, in the best sort of melody and music that may be conveniently devised, having respect that the sentence of the hymn may be understanded and perceived. ${ }^{32}$

The phrase 'or suchlike song' opened up the possibility that music other than hymns sung by choirs or music provided by an organ could be used in the service, leaving a gap which allowed the congregational singing of metrical psalms. ${ }^{33}$ Indeed, this instruction could also be read as suggesting that the Elizabethan authorities recognized that the process of institutionalization of psalm singing had already begun in the parishes. Again, it challenges Kümin's analysis by demonstrating how the singing of metrical psalms moved from inspirational origins towards a more institutionalized role in the worship of English congregations.

We have noted that the first complete edition of metrical psalms was published in 1562 under the title The Whole Booke of Psalmes. ${ }^{34}$ From the outset, the book declared that it could be used first in a domestic, then in a congregational, setting. The title page declared that it was '[v]ery mete to be vsed of all sortes of people priuately for their solace \& comfort', while that of editions printed from 1566 onwards stated that the psalms were 'to be sung in all churches, of all the people together ... and moreover in private houses, for their godly solace and comfort'. ${ }^{35}$ In this change we can see how the singing of metrical psalms was developing from its Edwardian origins as a domestic devotional practice, through the Marian exile and the lessons regarding adaptation for congregational use learnt by English congregations on the Continent, and now, through inspirational initiative, was slowly developing an institutionalized role in the worship of English congregations. The following sections will examine three strands of evidence which allow us to trace the process by which this practice became institutionalized during the first two decades of Elizabeth's reign.

32 Gerald Bray, ed., Documents of the English Reformation (Cambridge, 2004), 345.

33 Marsh, Music and Society, 401-2, 407. Marsh explains that "[t]he term "hymn" referred to any song of praise, whether or not its text was based squarely on a Scriptural passage': ibid. 407.

34 The Whole Booke of Psalmes, collected into Englysh metre, RSTC 2430 (London, 1562).

35 Ibid., sig. †1r; The Whole Boke of Psalmes, collected into English metre, RSTC 2437 (London, 1566), sig. A1r. 


\section{Prefatory Material and the Movement into Worship}

Alongside metrical versions of the psalms and tunes to which they could be sung, the Whole Booke of Psalmes contained additional prefatory material, whose function was to explain the texts and tunes and offer direction for individuals and congregations on how best to utilize the contents. The first item, 'A Treatise made by Athanasius the great', elevates the importance of the Psalms within Scripture and outlines over ninety circumstances in which psalms may be sung. For example, the treatise suggests: 'If thou hast need of prayer for them which withstand thee and compass thy soul about, sing the 17th Psalm and 86th, 89th, and 142nd Psalm'; and 'If thou wilt sing particularly of the saviour, thou hast of him in every Psalm, but specially in the 25th and 110th Psalm. ${ }^{36}$

After the Athanasian treatise there is a second item, 'The vse of the rest of the Psalmes not comprehended in the former Table of Athanasius'. This second list has two functions which root the use of the psalms in an Elizabethan setting. First, the list provides direction for individuals: 'If thou desirest to be just and virtuous, use the 33rd Psalm'; 'If thou be afflicted with any sickness and wouldst fain live and see good days and Christ's glory to be increased, use the 39th Psalm'. ${ }^{37}$ Second, the list offers directions which could be applied more readily to the Elizabethan church, as well as the wider world: 'If thou seest the nobility, the Council, the magistrates, and princes not given to religion nor to the praising of God, use the 29th Psalm'; 'If thou neither wouldst have idolatry neither any licentious lusts reign in Christ's commonwealth, thou must give God thanks, if thou be persuaded he both will and can take them away, using the 81st Psalm'; 'To sing praises to God for his mercies, use the 134th Psalm.' ${ }^{38}$ These latter examples in particular could readily be applied in a congregational setting, and they may have made the transition from private to institutionalized corporate worship more fluid.

This second, shorter preface did not appear in editions of the Whole Booke of Psalmes printed after 1577.39 Beth Quitslund has argued that the reason for this is because its tone was 'so close to what would come to be called "puritan", although she does not

36 Whole Booke of Psalmes, RSTC 2430, sigs $\dagger 6 \mathrm{v}-\mathrm{A} 2 \mathrm{v}$.

37 Ibid., sigs A3r-v.

38 Ibid.

39 Quitslund and Temperley, Whole Book of Psalms, 2: 575, 627. 
provide any clear rationale for this judgement. ${ }^{40}$ In 1577 both 'the use of the rest' and the 'Athanasian Treatise' were replaced by a different translation of the latter by Archbishop Parker. ${ }^{41}$ Quitslund and Temperley suggest a link between Richard Day's renewal of the patent to print the Whole Booke of Psalmes and the removal of the original 'Athanasian Treatise' and 'the use of the rest' (with their 'rather pointedly political occasions and uses') and their replacement with Parker's translation. ${ }^{42}$ While this does seem possible, the removal of the original prefaces could also imply that the singing of metrical psalms was becoming increasingly central to congregational worship in this period, so that there was less need for these prefatory texts outlining how and when to sing specific psalms. There is no guarantee that the Parker preface was studied in detail, and his directions could apply to either individual or congregational use, particularly if the singing of metrical psalms was institutionalized in the worship of congregations. It seems plausible that by 1577 , congregations were singing metrical psalms as an important part of their public worship, and that they knew the texts and tunes they wanted to sing (as discussed further below) and understood the directions which had been given in 'The vse of the Rest of the Psalmes'; presumably they could refer to an edition of the Whole Booke of Psalmes which contained it should they require additional direction.

The two original prefaces functioned as a bridge between the origins of the singing of metrical psalms in domestic devotions and their increasingly widespread inclusion in the worship of English congregations. Their removal by the late 1570 s suggests that the singing of metrical psalms had moved from its inspirational origins in private devotions, through a stage of inspirational inclusion in the service, towards a more institutionalized role in worship. This institutionalization can also be seen in the purchasing recorded in churchwardens' accounts and the increasing number of references by contemporary commentators to the popularity of the practice. ${ }^{43}$ Moreover, this

\footnotetext{
40 Quitslund, Reformation in Rhyme, 228. This suggestion is carried into Quitslund and Temperley, again without any clarity on which elements are controversial: Whole Book of Psalms, 2: 551-2, 574-5.

41 While the author is not named, the text was first published in Parker's Whole Psalter Translated into English Metre (1567): Quitslund and Temperley, Whole Book of Psalms, 2: $574,882$.

42 Ibid. 2: 574-5.

43 Marsh, Music and Society, 406-11, 435-53.
} 
institutionalization was cemented only a year later with the publication of the service to celebrate the accession of Elizabeth I (outlined in detail below), which acted as an important marker in the move of congregational singing of metrical psalms from inspiration to institutionalization. If the removal of the prefaces and the move of congregational singing towards a central place in parish worship were taking place together, they may provide evidence both for the influence that the singing of metrical psalms was exerting on the population and Elizabethan policy, and also for the extent to which the regime was beginning to take seriously the place of congregational singing of metrical psalms in public worship and to recognize the possible influence that might be exerted through it.

In the 1562 Whole Booke of Psalmes, alongside these prefatory treatises on the texts, a musical preface was printed: 'A short Introduction into the Science of Music'. ${ }^{44}$ This outlines the widespread practice of solmization known as the Gamut: the most widespread system of musical learning in Europe from the Middle Ages until the late sixteenth and early seventeenth century. ${ }^{45}$ The preface was intended '[f]or that the rude and ignorant in Song, may with more delight[,] desire, and good will: be moved and drawn to the godly exercise of singing of Psalms, as well in common place of prayer, where all together with one voice render thanks and praises to God, as privately by themselves, or at home in their houses'. ${ }^{46}$ It explained that individuals who did not know how to pitch the six notes, 'must learn to tune aptly of some one that can already sing, or by some Instrument of music, as the Virginals'. ${ }^{47}$ The suggestion that tunes be learnt through using musical instruments is particularly interesting, since instruments accompanied the singing of the psalms in Al Suche Psalmes, both in the Edwardian court and in domestic devotions. ${ }^{48}$ The implication here could be that metrical psalms were still being performed in domestic settings, so that individuals could learn the psalms at home (either through their own musical abilities or those

\footnotetext{
44 Whole Booke of Psalmes, RSTC 2430, sigs $\dagger 2 \mathrm{r}-7 \mathrm{r}$.

45 Andrew Hughes and Edith Gerson-Kiwi, 'Solmization', in Grove Music Online, 20 January 2001, at: <https://doi.org/10.1093/gmo/9781561592630.article.26154>, accessed 2 May 2019.

46 Whole Booke of Psalmes, RSTC 2430, sig. $\dagger 2 \mathrm{r}$.

47 Ibid., sig. $\dagger 4 \mathrm{r}$.

48 See my forthcoming thesis. For a discussion of Edwardian musical accompaniment, see Quitslund and Temperley, Whole Book of Psalms, 2: 510-27.
} 
of others) and, once the tunes were familiar, could use them in congregational worship. Quitslund suggests that the presence of this preface 'demonstrates considerably more confidence about the role of psalm-singing during or at least immediately before and after Prayer Book services than the title page' of the Whole Booke of Psalmes. ${ }^{49}$ From 1569, however, a shorter preface entitled 'To the Reader' often replaced the longer 'Introduction', and the longer treatise does not appear in any surviving copy after 1583.50 The shorter preface developed a system of placing sol-fa letters before the notes used for the tunes in the Whole Booke of Psalmes, so those who were reading the music understood the pitching of each note: essentially a visual aid for the solmization explained in the longer 'Science of Music' preface. ${ }^{51}$ Samantha Arten suggests that the printing of these letters may have been 'intended to accommodate those with less formal education' and in this way, 'the [Whole Booke of Psalmes] advocated musical literacy for the common people, not just those formally trained in music' ${ }^{52}$ Arten, however, implies that the key impetus in this shift towards solmization syllables comes from the publishers of the Whole Booke of Psalmes and so does not fully address the role of the 'common people' in this shift. In particular, she does not consider the possibility that the singing of metrical psalms had become an institutionalized, central element in public worship, and that the preface thus had limited utility once congregations knew which tunes they wanted to sing and how to sing them. As Timothy Duguid has shown, the evidence for such congregational understanding is seen in the printing of tunes which contained variations from those printed by the original printer of Sternhold and Hopkins in England, John Day. These variations seem to be based on variations in performance practice, and suggest the possibility that congregations were increasingly comfortable mixing and matching tunes and texts based on singers' knowledge, preferences, and abilities'. ${ }^{53}$ The possibility is instructive, and suggests that the relationship between the printers (especially John Day) and those using the Whole Booke of Psalmes was fluid, with each party responding to

\footnotetext{
49 Quitslund, Reformation in Rhyme, 204.

50 Quitslund and Temperley, Whole Book of Psalms, 2: 872, 881.

51 Whole Booke of Psalmes (1569), sig. A1v.

52 Samantha Arten, 'The Origin of Fixed-Scale Solmization in The Whole Booke of Psalmes', Early Music 46 (2018), 149-65, at 159.

53 Duguid, Metrical Psalmody, 116-17.
} 
and directing the changes of the other. ${ }^{54}$ In this process we see the fluidity which the categories of 'inspiration' and 'institution' bring: while the singing of metrical psalms had established itself as a central element in the worship of English congregations, inspirational innovation and development, whether directed by individuals, congregations or printers, was still present, although it too could become institutionalized over time.

The earlier, longer 'Introduction' demonstrates that by 1562, English congregations were incorporating the singing of metrical psalms as a central part of their worship services. This preface had not appeared in editions printed before the Marian exile; nor was it part of editions used by English congregations in continental exile. Its appearance in 1562 gives us a snapshot of changing patterns of metrical psalmody in the Elizabethan period. The omission of the longer musical preface and the addition of the shorter sol-fa version would have been a risky move for John Day if individuals or congregations still required direction in how to understand and utilize the music. We can, therefore, surmise that individuals using the Whole Booke of Psalmes in private devotions understood how they wanted to use the texts and tunes, possibly learning the melodies through instrumental accompaniment, while congregations who were singing metrical psalms had someone who understood how to read the music and lead the congregation, or who knew the tunes and could lead the congregation through singing or with musical accompaniment, or else congregations had developed a limited corpus of tunes (possibly incorporating 'common tunes') and did not require direction. These possibilities should also be considered alongside Christopher Marsh's assertion that '[e]arly modern people were thoroughly accustomed to picking up melodies by ear, and the evidence from balladry suggests that they could hold hundreds of tunes in their memories. 55 Thus, as with the textual treatises discussed above, the presence of these two prefaces on the music in the Whole Booke of Psalmes demonstrates that the singing of metrical psalms was becoming institutionalized and moving away from its inspirational origins as individuals and congregations grew more familiar with the texts and tunes found in the work.

One final indication of the presence of the singing of metrical psalms in the services of English congregations is the binding of

54 Ibid., especially 111-18.

55 Marsh, Music and Society, 426. 
the Whole Booke of Psalmes together with the Book of Common Prayer, the Bible or both. My initial survey of twenty-three surviving copies of the Whole Booke of Psalmes dated 1562-79 revealed that nine (i.e. 39 per cent) of the surviving copies of the Whole Booke of Psalmes were bound with a prayer book between 1562 and 1579, and that the practice was particularly prominent during the $1570 \mathrm{~s} .{ }^{56}$ This phenomenon demonstrates the intersecting movement of these two texts: the institutional Prayer Book being increasingly used in domestic devotion, where the singing of metrical psalms had originated and still continued, as outlined above, while the inspirational Whole Booke of Psalmes moved towards a more established role in public worship. It seems highly unlikely that domestic owners or churches would have bound the two texts together unless they were using both in both contexts. We can see, therefore, in these shared bindings, the movement of the singing of metrical psalms from its inspirational origins towards a more established, institutionalized place in the worship of English Protestant congregations and individuals, particularly during the 1570 s.

\section{The Singing of Metrical Psalms in Occasional Services}

The singing of metrical psalms by English congregations was further institutionalized when, in 1576, Elizabeth's government ordered all congregations to participate in a special service on 17 November to celebrate the anniversary of the queen's accession. The conclusion of The Fourme of Praier with Thankes Giuing includes the instruction: 'The xxi psalm in meter before the sermon, unto the end of the vii verse. And the c psalm after the sermon. ${ }^{57}$ This was the first time that the singing of metrical psalms had been officially required by

\footnotetext{
56 I examined 23 copies of the Whole Booke of Psalmes published between 1562 and 1579 , held by four repositories. Of these, 8 were printed in the 1560 s, of which 2 were also bound with the Book of Common Prayer [hereafter: BCP] (or 25\%), while 15 were printed in the 1570 s, with 7 of these bound with the BCP (46\%). In total, 9 of the 23 were bound with a BCP. The first edition of the Whole Booke of Psalmes to be bound with a BCP from the copies I examined was from 1566. Those editions of the Whole Booke of Psalmes bound with a BCP were located as follows: three in the British Library, two in the Bodleian Library, three in Cambridge University Library, and one in the library of Christ Church, Oxford.

57 The Fourme of Praier with Thankes Giuing, to be Used Every Yeere, the 17 of November, RSTC 164795 (London, 1576).
} 
the Elizabethan authorities and it is interesting that no mention is made in the Fourme of Praier as to which version of the metrical psalms is to be sung, or to which tune, much less a text provided. This reflects the widespread use of the Whole Booke of Psalmes by this date and the familiarity of English Protestants with this version. Both these psalms have music printed alongside them in the Whole Booke of Psalmes, so congregations would not have had difficulty integrating them into the service. We can also, however, see intention in the prescription of these two psalms. Psalm 21 speaks of God's blessings upon 'the king', declaring: 'Thou didst preuent him with thy giftes, and blessinges manifolde' (v. 3); 'great is his glory by thy helpe, thy benefite and ayde' (v. 5); 'Thou wilt geue him felicitye, that neuer shall decay' (v. 6). ${ }^{58}$ Additionally, Psalm 21 is prescribed in the preface discussed above, 'The vse of the rest of the Psalmes', where it is asserted: 'If thou wouldst prayse God because he hath geuen vs a good prince, which will and dooth punish the enemies of Christes religion. vse the 21 . Psalme.'59 It seems highly likely that congregations and individuals who were familiar with the Whole Booke of Psalmes would have been familiar with the use of this psalm in the same context as that directed in the Fourme of Praier; thus prescribing it for that service would not have been a dramatically new use of it for Elizabethan congregations.

Psalm 100, on the other hand, is simply a hymn of praise, exhorting 'All people that on earth do dwell,' to 'Sing to the Lord with cherefull voyce'. ${ }^{60}$ Another version of Psalm 100, sometimes set to music (though not that in the Whole Booke of Psalmes), would have been known to English congregations since it had been prescribed in the 1552 and 1559 Prayer Books as the Jubilate Deo, to be sung after the second lesson of Morning Prayer, 'as an alternative canticle ... because the Benedictus is sometimes the lesson or Gospel of the day'. ${ }^{61}$ Additionally, the Athanasian treatise at the beginning of the Whole Booke of Psalmes directed: 'If thou markest the providence of the Lord in all things, and the Lord of the same, and wouldst instruct any with the faith and obedience thereof, when thou hast persuaded

\footnotetext{
58 The Whole Booke of Psalmes, collected into Englishe metre, RSTC 2447 (London, 1576), sigs $\mathrm{B} 4 \mathrm{r}-\mathrm{v}$.

59 Whole Booke of Psalmes, RSTC 2430, sig. A3r.

60 Whole Booke of Psalmes, RSTC 2447, sig. F1v.

61 Brian Cummings, ed., The Book of Common Prayer: the texts of 1549, 1559, and 1562

(Oxford, 2011), 109-10, 724-5.
} 
them first to acknowledge, sing the 100th Psalm.' ${ }^{62}$ While this is a less explicit direction than that for Psalm 21, it is possible that this had resonance with congregations and individuals, and, again, the order to sing it in the service to celebrate the queen's accession may have fitted with a common interpretation of this direction. By choosing both these psalms, therefore, those who created the Fourme of Praier presumably recognized that in doing so they were satisfying the desire of those who wanted the singing of metrical psalms to be acknowledged by the Elizabethan state and accepted officially as an integral part of public worship, but they also understood that the singing of psalms could be used to serve their own purposes, as in this service. ${ }^{63}$

It is also worth noting that the preface on 'The vse of the Rest of the Psalmes' (discussed above) ceased to appear in editions of the Whole Booke of Psalmes published in the late 1570s, around the time that The Fourme of Praier with Thankes Giuing was published. It is possible that the publishing of this liturgy marked the point at which congregations were settling into fixed habits and customs regarding which psalms could or should be sung for different purposes and how they wanted to utilize the texts and tunes within the Whole Booke of Psalmes, and also a point at which the Elizabethan authorities began to utilize the practice for their own ends, instructing congregations to sing metrical psalms for particular purposes. This direction by the authorities would continue throughout the remainder of Elizabeth's reign, as discussed below.

Returning to our dichotomy of 'inspiration' versus 'institution', we note that the direction to sing psalms in metre marks the movement of the singing of metrical psalms from its 'inspirational' origins towards a mandated institutionalization. Yet even by this date, there was no explicit direction that the singing of metrical psalms was to form a regular part of the worship of English parishes. Its institutionalization came about as it became a regular part of the worship of English congregations, developing initially as a grassroots initiative, but then being reinforced and given official approval in the direction for congregations to sing metrical psalms during the annual service to celebrate Elizabeth's accession. This process of institutionalization advanced further in 1580 when, following an

62 Whole Booke of Psalmes, RSTC 2430, sig. A2r.

63 Marsh, Music and Society, 409. 
earthquake, the Elizabethan authorities published a liturgy to be used 'vpon Wednesdayes and Frydayes, to auert and turne Gods wrath from vs'. ${ }^{64}$ This liturgy provided an order which included psalms, readings from Joel and Isaiah, a prayer, and Psalm 46 in metre, which reminds the singer that 'The Lord is our defence and aid ... Though thearth remoue, we will not feare, though hils so high and steepe: Be thrust and hurled here and there, within the sea so deepe.' ${ }^{65}$ In this liturgy, unlike that devised to celebrate the queen's accession, both the words and a tune are printed for people to use; however, whilst the words are the same as those found in the Whole Booke of Psalmes, the tune is different. Moreover, this tune does not appear in the Whole Booke of Psalmes; neither is it one of the 'Common Tunes'. It is possible, therefore, that this tune was devised specifically for this service, suggesting that Elizabeth's government understood the power of uniting congregations in one text and tune.

In addition, key moments in English history throughout this period were marked by psalm-singing. In 1586, after the Babington plot to kill the queen was foiled, John Strype reported that 'the city of London made extraordinary rejoicings, by public bonfires, ringing of bells, feastings in the street singing of psalms, and such like'. ${ }^{66}$ Two years later, on 19 November 1588, John Stowe recounted that a holiday was kept 'throughout the realme, with sermons, singing of Psalmes, bone-fires. \&c. For ioy, and a thanks giuing unto God, for the ouerthrow of the Spanyards our enimies on the sea'. ${ }^{67}$ Strype also recorded that ' $[t]$ here was a prayer and psalm, appointed to be used duly in the parish-churches on this joyful occasion'. ${ }^{68}$ This was not a metrical psalm, but rather a cut-and-paste psalm made up of various references from Scripture and the psalter, rearranged to make a 'psalm'. ${ }^{69}$ Yet the psalm singing which Strype

64 The Order of Prayer, and Other Exercises upon Wednesdayes and Fridayes, RSTC 16512 (London, 1580), title page.

65 Ibid., sig. 3v.

66 John Strype, Annals of the Reformation and Establishment of Religion, 4 vols (Oxford, 1824), 3/i: 607.

${ }^{67}$ John Stowe, The Annales of England, RSTC 2334 (London, 1592), sig Ppppi.r.

68 Strype, Annals, 3/ii: 28.

69 A Psalme and Collect of Thanksgiuing, not vnmeet for this present time: to be said or sung in Churches, RSTC 16520 (London, 1588), sigs A2r-A3v. For a discussion of cut-andpaste psalms, see Ryrie, 'Psalms and Confrontation', 116-18. 
records seems most likely to have been singing of metrical psalms, demonstrating further how they had become institutionalized: now, the singing of metrical psalms had become a natural celebratory response for the nation. This practice, and the Whole Booke of Psalmes itself, developed over the course of the following century and a half, though not dramatically. The melodies slowed, and the corpus of regularly sung psalms seems to have diminished, yet the singing of metrical psalms continued to form an important part of the worship of English congregations, to be used by individuals in domestic devotion, and to be appointed during times of national celebration, until it encountered competition from new forms and settings of metrical psalms in the late seventeenth and early eighteenth centuries, and was later replaced by hymns in the late eighteenth and early nineteenth centuries. ${ }^{70}$

\section{Conclusion}

Through the lens of the Whole Booke of Psalmes, this article has argued that the dichotomy of inspiration versus institution provides a nuanced and fruitful framework for understanding lay religious devotion during the English Reformation. The 'voluntary' versus 'official religion' framework outlined at the beginning does not provide space for the singing of metrical psalms, a practice which was not the sole preserve of 'groups' or 'communities', and was neither explicitly prescribed nor proscribed by the Elizabethan authorities but emerged through inspirational lay initiative. A framework constructed around the relationship between institution and inspiration makes it possible to study a larger web of lay religious activity, but also the diverse ways in which inspirational practices became institutionalized. Additionally, this new framework reveals the interaction between institution and inspiration (seen in the prefatory material in the Whole Booke of Psalmes) as the latter became more established and thus embedded in the former. In the opening example from Exeter, we see institutionalization at work in the approval of Bishop-elect Jewel and Archbishop Parker for the laity to continue singing psalms, despite there being no explicit direction for them to do so in the

70 For the slowing of melodies, and possible reasons for this, see Marsh, Music and Society, 430-4. For the longevity of Sternhold and Hopkins see Marsh, Music and Society, 40553, especially 435-53; Green, “'All people that on earth do dwell”'. 
Elizabethan settlement, while inspiration is evident in the singers and (by reaction) the clergy who viewed such singing as unwelcome and unlawful. As the Exeter example shows, inspiration could still arise during the process of institutionalization, as in the rise of the common tunes, particularly in the mid-to-later Elizabethan period, and in the practice of binding the metrical psalms with the Book of Common Prayer and Bible. This latter point also demonstrates the two phases of institutionalization, within both of which inspiration continued to operate, so that there was a fluid movement of metrical psalm singing between the domestic and congregational settings. The framework proposed may contribute towards renewing our understanding of the interplay between inspiration and institution in the English Reformation. 